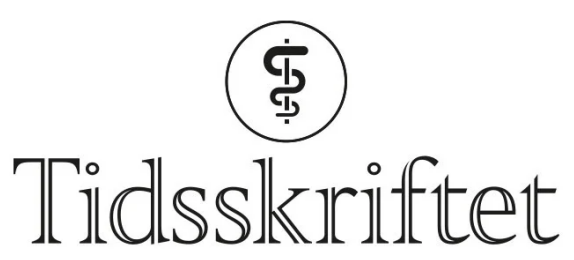

DEN NORSKE LEGEFORENING

\title{
En ekstraordinær undersøkelsesform
}

\section{ANMELDELSER}

\section{STEIN A. EVENSEN}

Fakultetsdivisjon Rikshospitalet Universitetet i Oslo

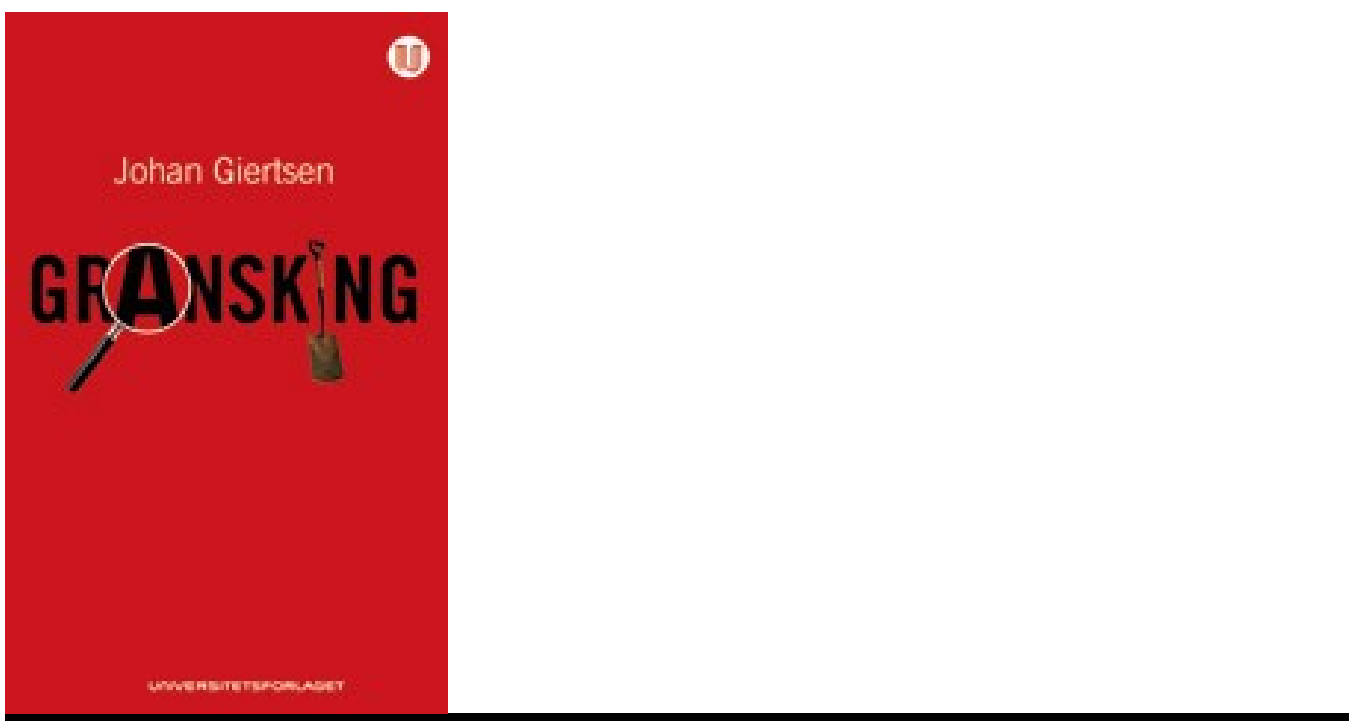

Giertsen, J.

Gransking

270 s. Oslo: Universitetsforlaget, 2008. Pris NOK 399

ISBN 978-82-15-01234-6

Når noe går galt, kommer kravet om gransking fort opp. Men hva skiller gransking fra hva vi på godt norsk kaller en undersøkelse? Forfatteren mener betegnelsen "gransking» bør forbeholdes spesielt grundige undersøkelser som iverksettes etter større ulykker (f.eks. Alexander Kielland-ulykken i Nordsjøen, gruveulykken på Svalbard eller Scandinavian Starbrannen) eller andre ekstraordinære begivenheter der det reises spørsmål om brudd på lov eller om skjønn innen lovens ramme har vært forsvarlig (eksemplifisert ved granskinger av Fritz Moen-saken, mulig misligheter i Oslo kommune eller Lillehammer-drapet). 
Denne avgrensningen har sine problemer, ettersom ordet "gransking» i dagligtale anvendes vesentlig bredere. Forfatteren, som er professor i rettsvitenskap, erkjenner at betegnelsen ikke er entydig og påpeker også at det foreløpig ikke finnes lovverk som regulerer området. Avgrensningen oppleves likevel som nyttig. Når styret i en institusjon starter undersøkelser, ligger dette i de fleste tilfeller innen det tilsyn og kontrollarbeid som et styre er pålagt gjennom sin instruks. Slike undersøkelser utføres som oftest av ansatte, eventuelt supplert med eksperter på særskilte områder. Gransking dreier seg om vesentlig mer alvorlige forhold og kjennetegnes ved at de som utfører arbeidet skal være uavhengige av institusjonen og at andre enn granskingsutvalget har ansvaret for oppfølging av utvalgets rapport.

Dette er ingen lett tilgjengelig bok for ikke-jurister. Målgruppen er jurister, og teksten er tung og særdeles detaljert inndelt i titler, undertitler, punkter og underpunkter som jurister liker så godt. Likevel er boken av interesse også for andre, og særlig ledere på høyt nivå i store institusjoner. Når en situasjon oppstår som fordrer gransking, er det lett å trå feil. Mye kunne blitt annerledes hvis de som styrte Valla-saken, hadde lest denne teksten på forhånd. Innledningskapitlet og kapitlet som drøfter etablering av granskingsutvalg er særlig leseverdige for ikke-jurister. Som dekanus ved Det medisinske fakultet satt jeg sentralt i granskingen av forskningsskandalen begått av Jon Sudbø, og nikker gjenkjennende til de situasjoner og avveininger som forfatteren gjør. Hensynet til tillit og rettssikkerhet står helt sentralt i vurderingen av om man skal iverksette det store apparatet som en gransking innebærer.

Boken inneholder en oversikt over 68 granskingsrapporter avgitt i perioden 1945-2008. Det er litt uklart om dette er et utvalg blant - eller en fullstendig opplisting av-rapporter som fyller forfatterens definisjon av gransking. Her finnes det imidlertid bare tre eksempler på granskinger knyttet til helsevesenet. Det er Reitgjerdet-rapporten fra 1980, Sudbø-saken fra 2006 og rapporten fra utvalget som gjennomgikk meningokokkforsøket fra 2007.

Jeg tror helsevesenets ledere bør forberede seg på flere granskinger i årene som kommer. Da bør denne boken fiskes ned fra bokhyllen før arbeidet settes i gang.

Publisert: 17. desember 2009. Tidsskr Nor Legeforen. DOI: 10.4045/tidsskr.09.1238

(C) Tidsskrift for Den norske legeforening 2023. Lastet ned fra tidsskriftet.no 26. april 2023. 